\title{
Prinsip moralitas merek dalam undang-undang nomor 20 tahun 2016 tentang Merek dan Indikasi Geografis
}

\author{
Sulthon Miladiyanto ${ }^{1}$, Ariyanti ${ }^{2}$
}

1 Sulthon Miladiyanto; Fakultas Hukum Universitas Widyagama Malang; Jl. Borobudur No. 35; Malang; 65128; Jawa Timur; Indonesia.

${ }^{2}$ Ariyanti; Fakultas Hukum Universitas Merdeka Malang; Jl. Terusan Raya Dieng Nomor 62-64; Malang; 65146; Jawa Timur; Indonesia.

\begin{tabular}{l} 
A R T I C L E IN F O \\
\hline Article history: \\
Received 2020-09-09 \\
Received in revised form \\
2020-10-12 \\
Accepted 2020-12-01 \\
\hline Kata kunci: \\
Merek; Moral; Hak Kekayaan \\
Intelektual. \\
\hline
\end{tabular}

Keywords:

Merk; Morals; Intellectual Property Rights.

DOI: https://doi.org/10.26905/

idjch. v11i3.5022.

\section{How to cite item:}

Miladiyanto, S., \& Ariyanti, A. (2020). Perinsip moralitas merek dalam undang-undang nomor 20 tahun 2016 tentang Merek dan Indikasi Geografis. Jurnal Cakrawala Hukum, 11(3)., 241-249. doi:10.26905/ idjch.v11i2.5022.

\section{Abstrak}

Tanggung jawab negara unruk menjaga moralitas masyarakat salah satunya dengan cara memberi rambu-rambu dalam pembuatan merek dagang barang maupun jasa. Penelitian hukum dengan pendekatan filsafat untuk mendapatkan makna Merek tidak boleh bertententangan dengan dengan moralitas yang berlaku di masyarakat. Merek bermoral merupakan merek yang dinilai masyarakat yang sifatnya universal mengenai baik-buruknya suatu perbuatan yang dinilai dari rasio maupun trasendetal dengan melibatkan tujuan.

\section{Abstract}

The responsibility of the state cannot maintain the morality of the people, one of which is by providing signs in making trademarks for goods and services. Legal research with a philosophical approach to get the meaning of Brand must not conflict with the prevailing morality in society. A moral brand is a brand that limits society which is universal regarding the pros and cons of an act of both ratio and tracendetal involving the goal.

Corresponding Author:

* Sulthon Miladiyanto.

E-mail address: bossulthonmiladiyanto@gmail.com 


\section{Jurnal Cakrawala Hukum, Volume 11 No. 3 Desember 2020}

ISSN PRINT 2356-4962 ISSN ONLINE 2598-6538

\section{Pendahuluan}

World Trade Organization (WTO) yang Indonesia ikut didalamnya, membuat stadar minimum untuk pengaturan Hak Kekayaan Intelektual dengan The Agreement on Trade related Aspects of Intellectual Property Rights (TRIPs). Untuk memberi kepastian hukum dan terjalin hubungan internasional yang baik, TRIPs diadopsi dalam ranah hukum Indonesia. Pemerintah mengundangkan peraturan dalam bentuk tertulis dengan mempertimbangkan Peraturan yang telah ada seperti adanya Kitab Undang Undang Hukum Perdata/ KUHPerdata dan Kitab Undang Undang Hukum Dagang/ KUHDagang serta peraturan perundangan yang lain yang sifatnya lebih khusus dan peraturan pelaksana.

Beberapa istilah Intellectual Property/ Hak Kekayaan Intelektual yang digunakan Indonesia antara lain Hak Milik Immateril (Mahadi, 1985), Hak Milik Intelektual (Muhammad Junhana, 2003), dan Hak atas Kekayaan Intelektual (Eddy Damian, 2002) serta Hak Kekayaan Intelektual (OK Saidin, 2007).

Keputusan Menteri Hukum dan Perundang undangan RI Nomor. M.03.PR.07.10 Tahun 2000 dengan persetujuan Menteri Negara Pendayagunaan Aparatur Negara RI sesuai dengan surat Nomor 24/M/PAN/1/2000 secara resmi digunakan istilah Hak Kekayaan Intelektual (yang selanjutnya disebut HKI).

Pengaturan Hak kekayaan Intelektual di Indonesia yang harus menyesuaikan dengan TRIPs Agreement meliputi Hak cipta dan hak terkait juga milik Industri diantaranya Merek, Paten, Disain Industri, Varietas Tanaman, Rahasia Dagang, Tata letak Sirkuit Terpadu

Undang-Undang No 20 tahun 2016 tentang Merek dan Indikasi Geografis (untuk selanjutnya disebut UU MIG 2016) pada Bab IV Pendaftaran Merek, pada bagian kesatu,menerangkan merek yang tidak dapat didaftarkan dan ditolak. Pasal
20 Merek tidak dapat didaftar jika: a). bertentangan dengan ideologi negara,peraturan perundangundangan, moralitas, agama, kesusilaan, atau ketertiban umum; b). sama dengan, berkaitan dengan, atau hanya menyebut barang dan/atau jasa yang dimohonkan pendaftarannya; c). memuat unsur yang dapat menyesatkan masyarakat tentang asal, kualitas, jenis, ukuran, macam, tujuan penggunaan barang dan/atau jasa yang dimohonkan pendaftarannya atau merupakan nama varietas tanaman yang dilindungi untuk barang dan/atau jasa yang sejenis; d). memuat keterangan yang tidak sesuai dengan kualitas, manfaat, atau khasiat dari barang dan/atau jasa yang diproduksi; e). tidak memiliki daya pembeda; dan/atau f). merupakan nama umum dan/atau lambang milik umum.

Sedangakan dalam penjelasan Pasal 20 Huruf a yang dimaksud dengan "bertentangan dengan ketertiban umum" adalah tidak sejalan dengan peraturan yang ada dalam masyarakat yang sifatnya menyeluruh seperti menyinggung perasaan masyarakat atau golongan, menyinggung kesopanan atau etika umum masyarakat, dan menyinggung ketentraman masyarakat atau golongan. Huruf b merek tersebut berkaitan atau hanya menyebutkan barang dan/atau jasa yang dimohonkan pendaftarannya. Huruf c yang dimaksud dengan "memuat unsur yang dapat menyesatkan" misalnya Merek "Kecap No. 1" tidak dapat didaftarkan karena menyesatkan masyarakat terkait dengan kualitas barang, Merek "netto 100 gram" tidak dapat didaftarkan karena menyesatkan masyarakat terkait dengan ukuran barang. Huruf d yang dimaksud dengan "memuat keterangan yang tidak sesuai dengan kualitas, manfaat, atau khasiat dari barang dan/atau jasa yang diproduksi" adalah mencantumkan keterangan yang tidak sesuai dengan kualitas, manfaat, khasiat, dan/atau risiko dari produk dimaksud. Contohnya: obat yang dapat menyembuhkan seribu satu penyakit, rokok yang aman bagi kesehatan. 


\section{Prinsip moralitas merek dalam undang-undang nomor 20 tahun 2016 tentang Merek dan Indikasi Geografis}

Sulthon Miladiyanto, Ariyanti

Huruf e tanda dianggap tidak memiliki daya pembeda apabila tanda tersebut terlalu sederhana seperti satu tanda garis atau satu tanda titik, ataupun terlalu rumit sehingga tidak jelas. Huruf fyang dimaksud dengan "nama umum" antara lain Merek "rumah makan" untuk restoran, Merek "warung kopi" untuk kafe. Adapun "lambang milik umum" antara lain "lambang tengkorak" untuk barang berbahaya, lambang "tanda racun" untuk bahan kimia, "lambang sendok dan garpu" untuk jasa restoran.

Jika kita cermati dari Pasal 20 dan penjelasan Pasal 20 tersebut terjadi kekaburan Norma pada Pasal 20 huruf a klusula kata moralitas, dimana kata moralitas tersebut tidak dijelaskan pada penjelsan Pasal 20 huruf a. Kekaburan norma tentang kriteria merek yang bertentangan dengan moralitas ini dapat mengakibatkan kepastian hukum tidak dapat dipenuhi. Sangat dimungkinkan terjadi peristiwa,suatu perusahaan mendaftarkan merek ke dirjen HKI kemudian dirjen HKI dengan serta merta yang bersifat subjektif menyatakan tidak dapat diterima dikarenakan bertentangan dengan moralitas, atau memberi penjelasan tetapi substansi penolakannya yang seolah-olah bertentangan dengan moralitasyang sebenarnya masih dapat diperdebatkan atau merek yang telah terdaftara kemudian dibatalkan secara sepihak oleh Dirjen HKI dengan alasan bertentangan dengan moralitas.

Peristiwa, Ms tarja Visan warga negara Perancis dengan dibawah Perusahaan George Eatertaiment, mendaftarakan merek "BUDDHA BAR" pada Juni 2007 ke Kementrian Hukum dan Ham Dirjen Hak Kekayaan Intelektual. Pendaftaran ini telah melalui pemeriksaan subtantif dan pengumuman selama 3 (tiga) bulan dalam berita resmi Merek yang kemudian di setujui oleh Kementrian Hukum dan Ham cq Dirjen Hak Kekayaan Intelektual cq direktur Merek dengan mengeluarkan sertifikat merek nomor IDM 000189681 untuk merek "BUDDHA BAR" Di kelas 43 digunakan untuk usaha restoran dan bar pada tanggal 16 Januari 2009 yang dalam hal ini telah sesuai dengan maksud pendaftaran. Tetapi saat beroprasi restoran Buddha Bar memunculkan keresahan di lingkungan umat Buddha dan penolakan sektesekte dalam agama Buddha secara tertulis maupun fisik (demonstrasi) terhadap keberadaan " Buddha Bar" sebagaimana tertuang dalam Surat Direktur Jenderal Binmas Buddha Departemen Agama tertangga l 12 Maret 2009 dan tanggal 6 April 2009, Surat Pernyataan Sikap dari Forum Anti Buddha Bar (FABB) tertanggal 23 Februari 2009, Petisi Umat Buddha Mengenai Penolakan Merek Buddha Bar tertanggal 02 April 2009 dan Permo honan Pencabutan Merek Dagang Buddha Bar dari Forum Anti Buddha Bar tertanggal 02 Maret 2009. Sehingga Pada 15 April 2009 Kementrian Hukum dan ham $\mathrm{Cq}$ direktur Merek mengeluarkan surat nomor HKI.4.HI.06.03-98/2009 yang isinya adalah penarikan kembali sertifikat merek nomor IDM 000189681 untuk merek "BUDDHA BAR" Dasar yang digunakan oleh Direktur merek tersebut adalah Pasal 5 Huruf a UU Nomor 15 tahun 2001 tentang merek, yang selengkapnya mengatur: merek tidak dapat didaftar apabila merek tersebut mengandung salah satu unsur di bawah ini: a. bertentangan dengan peraturan perundang-undangan yang berlaku, moralitas agama, kesusilaan atau ketertipan umum. Untuk lebih tepatnya bertentangan dengan moralitas agama dan ketertiban umum.

Pada tahun 2016 beredar produk makanan ringan dengan merek "bikini" dengan jargon "remas aku" di produksi oleh TW di Depok Jawa Barat yang belum terdaftar di BPOM dan MUI maupun Dirjen HKI (Republika, 2018), sehingga secara prinsip tidak mendapat perlindungan hukum. Produk ini menghebohkan dan meresahkan masyarakat dimana dalam kemasannya memperlihatkan gambar tubuh wanita yang memakai bikini dengan merek "bikini" dan tulisan "remas aku". Kehebohan dan keresahan masyarakat ini 
setidaknya menunjukan bahwa ada sesuatu yang tidak tepat dari merek tersebut yaitu penilaian yang amoral.Yang menjadi pertanyaan apakah itu yang di sebut bertentangan dengan moralitas?

Jawa Timur sebagai tempat beranekaragam kuliner banyak menawarkan segala jenis makanan dengan berbagai merek, yang terkadang mereknya unik dan bahkan aneh-aneh, diantaranya rumah makan bernama "mie setan", atau kalau di kota Surabaya terdapat "nasi goreng jancuk". Merek-merek tersebut senyatanya merupakan sesuatu yang memiliki makna yang tidak baik, tetapi masyarakat saat ini tidak mempermasalahkan walaupun masih banyak juga masyarakat yang merasa tidak nyaman.Apakah hal tersebut tidak bertentangan dengan moralitas?

Pembenahan dan memperjelas makna moralitas dalam pendaftaraan merek ini merupakan sesuatu yang penting demi menegakan fungsi negara untuk menjaga moralitas anak bangsa dari salah satu segi yaitu perdagangan, yang senyatanya saat ini moralitas anak bangsa kecenderungan menurun.

Problematika ini muncul karena ketidak jelasan makna moralitas sebagai syarat pendaftaran merek sebagaimana dalam UU MIG 2016 yang sementara ini hanya menjelaskan makna bertentangan dengan kepentingan umum. Sehingga perlu mencari tahu hakikat bertentangan dengan moralitas itu apa? Diharapkan mendapatkan gambaran yang utuh tentang merek yang tidak dapat didaftarkan dengan alasan yang bertentangan dengan moralitas itu dapat terjawab. Pertanyaan yang muncul adalah Apa hakikat tidak bertentangan dengan moralitas dalam pendaftaran merek di Indonesia?

\section{Metode}

Jenis penelitian ini adalah penelitian hukum atau legal research. Dengan pendekatan Pendakatan Filsafat (philosophical approach), yaitu pendekatan dengan menggunakan sifat-sifat filsafat. Dengan sifat filsafat yang menyeluruh, mendasar, dan spekulatif, penjelasan filsafat akan mengupas isu hukum (legal issue) dalam penelitian normative secara radikal dan mengupasnya secara mendalam. ${ }^{1}$ Dalam hal ini mengupas moralitas sebagai syarat diterimanya pendaftaran merek. Pendekatan konseptual (conceptual approach) yaitu pendekatan dengan doktrin-doktrin yang berkembang di dalam Ilmu Hukum berkenaan dengan moralitas.

Menggunakan data sekunder yaitu data yang telah jadi dalam bentuk dokumen meliputi bahan hukum primer, bahan hukum sekunder dan bahan hukum tersier. Metode Pengumpulan Bahan Hukum penelitian ini adalah studi dokumen (studi kepustakaan).Teknik ini berguna untuk mendapatkan kajian teori dengan mengkaji dan mempelajari buku-buku, peraturan perundang-undangan, dokumen, laporan, arsip dan hasil penelitian lainnya baik cetak maupun elektronik yang berhubungan dengan prinsip moralitas dalam pendaftaran merek. Teknik Analisa Bahan Hukum dianalisis secara preskriptif analitis untuk menghasilkan preskripsi sebagai argumentas baru dalam bidang hukum, khususnya mengenai prinsip moralitas dalam pendaftaran merek di Indonesia.

\section{Pembahasan}

\subsection{Penerapan klausula demurrage dalam perjanjian jual beli batubara di PT. sinar rejeki ekonomi}

Istilah prinsip dan asas dalam dunia hukum sering digunakan dan bahkan seringkali juga saling menggantikan sebagaimana dalam Kamus Besar Bahasa Indonesia yang memberikan makna serupa, sehingga banyak tokoh juga menyatakan antara prinsip dan asas itu sesuatu yang bermakna sama. Dalam Kamus Besar Bahasa Indonesia (KBBI) Prinsip memiliki arti (kebenaran yang menjadi pokok dasar berfikir, bertindak) dasar. 


\section{Prinsip moralitas merek dalam undang-undang nomor 20 tahun 2016 tentang Merek dan Indikasi Geografis}

Sulthon Miladiyanto, Ariyanti

Sedangkan asas memiliki arti dasar (sesuatu yang menjadi tumpuan berpikir atau berpendapat)

(Departemen Pendidikan dan Kebudayaan, 1989). Prinsip sebagai "a funadamental truth or doctrine, as af law; acomprenhensive rule or doctrine which furnishes a basis or original for athors (Henry Campbell, 1978). Prinsip adalah suatu pernyataan fundamental atau kebenaran umum maupun individual sebagai sebuah pedoman untuk berfikir atau bertindak. Sebuah asas merupakan roh dari sebuah perkembangan ataupun perubahan, dan merupakan akumulasi dari pengalaman ataupun pemaknaan oleh sebuah objek atau subjek tertentu.

Sudikno Mertokusumo berpendapat bahwa asas atau prinsip hukum bukanlah peraturan hukum kongkrit, melainkan merupakan pikiran dasar yang umum sifatnya atau merupakan latar belakang dari peraturan yang kongkrit yang terdapat dalam dan dibelakang setiap sistem hukum yang terjelma dalam peraturan perundangundangan dan putusan hakim yang merupakan hukum positif dan dapat diketemukan dengan mencari sifat-sifat umum dalam peraturan kongkrit tersebut (Sudikno, 2005).

Satjipto Raharjo menyatakan jika kita membicarakan asas hukum, maka pada saat itu kita membicarakan unsur penting dan pokok dari peraturan hukum. Barangkali tidak berlebihan apabila dikatakan, bahwa asas hukum ini merupakan “jantungnya” peraturan hukum (Rahardjo, 2005).

Sebelum mengkaji tentang moral lebih dulu kita harus mengerti tentang etika yang seringkali diartikan sama dengan moral, sejatinya etika dan moral adalah sesuatu yang berbeda. Kata Etika berasal dari bahasa yunani kuno, ethos. Kata ini dalam bentuk tunggal memiliki beberapa arti, yaitu tempat tinggal yang biasa, padang rumput, kandang, kebiasaan, adat, akhlak watak, perasaan, sikap, dan cara berfikir. Jadi berdasarkan asal-usul kata tersebut dapat dikatakan bahwa etika adalah ilmu tentang adat kebiasaan atau apa yang dilakukan. Namun pengertian etika dari sudut pandang ini belum cukup untuk menjelaskan secara lengkap tentang etika (Bertens, 2000).

Etika sering juga dikatakan sebagai pemikiran filosofis tentang apa yang dianggap baik atau buruk dalam perilaku manusia yang mengandung suatu tanggung jawab. Disebut sebagai pemikiran filosofis karena secara historis etika berkembang sejalan dengan perkembangan filsafat. Dalam filsafat yunani, etika bersumber dari spekulasi tentang kehidupan yang baik yang disistematisasikan ke dalam bagian filsafat dan disebut etika. Kata tersebut menunjuk pada "kebiasaan-kebiasaan" (custems), yaitu kebiasaan dalam arti ide tentang yang baik dan yang buruk dalam diri manusia (Khudzaifah, 2007).

Etika adalah ilmu pengetahuan tentang keseluruhan aturan, kaedah atau hukum yang mengambil bentuk amar atau larangan. Disamping itu sering juga dikatakan bahwa etika adalah filsafat tenteng ajaran moral. Maka dari itu etika berbeda dengan moral. Ajaran moral menjawab pertanyaan tentang bagaimana orang harus hidup, apa yang boleh, apa yang tidak boleh dan apa yang wajib di perbuat sedangakan etika menjawab pertanyaan bagaimana pertanyaan moral tersebut dapat dijawab (Suseno, 1991).

Moral berasal dari kata bahasa latin "mos" (tunggal), "mores" (Jamak) yang berarti Kebiasaan, kelakuan, kesusilaan dan kata sifat "moralis" berarti kesusilaan. Moralitas adalah objek filsafat moral. Menurut W. Poespoprodjo moralitas adalah kualitas dalam perbuatan manusia yang menunjukkan bahwa perbuatan itu benar atau salah, baik atau buruk. Moralitas mencakup pengertian tentang baik buruknya perbuatan manusia ( Poespoprodjo, 1999).

Menurut aristoteles (Aristotle, 1999) "Virtue, then, being of two kinds, intellectual and moral, intellectual vir-tue in the main owes both its birth and its growth to teaching (for whichreason it requires experience and time), while moral virtue comes aboutas a result of habit, whence also its name (ethike) is one that is 


\section{Jurnal Cakrawala Hukum, Volume 11 No. 3 Desember 2020}

ISSN PRINT 2356-4962 ISSN ONLINE 2598-6538

formedby a slight variation from the word ethos (habit)." Terjemahan bebas, kebajikan terdiri dari dua jenis, intelektual dan moral, kecerdasan intelektual pada pokoknya bersumber pada kelahiran dan pertumbuhannya pada pengajaran (karena alasan itu membutuhkan pengalaman dan waktu), sedangkan kebajikan moral muncul sebagai akibat dari kebiasaan, dari mana juga namanya (etike) adalah salah satu yang dibentuk oleh sedikit variasi dari kata etos (kebiasaan).

"Moral principles do at least three things that more regularities cannot do and, hence, that generalizations describing mere regularities cannot do, either. One thing that moral principles do is explain the phenomena "falling within their scope," which scope at least includes the instances of the laws they guarantee. A second thing that moral principles do is support counterfactuals, or counterfactual conditionals. A third thing that moral principles do is ground, "necessary connections" between right and wrong-making circumstances (events, states of affairs, etc.)" (Robinson, 2008). Terjemah bebas, Prinsip-prinsip moral melakukan setidaknya tiga

hal yang tidak dapat dilakukan oleh keteraturan biasa dan, karenanya, generalisasi yang menggambarkan keteraturan tidak bisa dilakukan juga. Satu hal yang dilakukan prinsip-prinsip moral adalah menjelaskan fenomena "termasuk dalam ruang lingkup mereka,"ruang lingkup yang setidaknya mencakup contoh-contoh hukum yang mereka jamin. kedua yang dilakukan prinsip-prinsip moral adalah mendukung kontrafaktual, atau kondisional kontrafaktual. ketiga yang dilakukan oleh prinsip-prinsip moral adalah kebutuhan moral dasar, "koneksi yang diperlukan" antara alasan wajib - keadaan yang membuat benar dan salah (peristiwa, keadaan, dll.)

a. Corak moral (Ridwan, 2017); 1). Humanism autrosetris Aliran filsafat yang menjadikan objek, sumber dan tujuan dari ilmu pengetahuan khususnya dan kehidupan manusia pada umumnya berpusat pada realitas empiris dan rasio manusia semata tanpa mengaitkannya dengan hal-hal yang bersifat transenden
(Wahyu dan Tuhan). Kebenaran ilmu pengetahuan diukur dari kesesuaian dengan fakta empiris yang terferifikasi. Tujuan manusia hanya untuk dunia kini semata tanpa melibatkan unsur dunia kelak (akherat). 2). Humanism teosentris, aliran pemikiran ilmu pengetahuan yang menjadi objeknya tidak saja dunia fisik (realitas empiris dan peran rasio) akan tetapi juga menjadikan realitas transcendental yang bersifat metafisik (Wahyu dan Tuhan) sebagai objek menggali ilmu pengetahuan. Secara etimologis humanism teosentris atau teopoantoposentris dalam mengontruksi ilmu pengetahuan tidak hanya membiarkan peran indra dan rasio, tetapi juga menjadikan intuisi bahkan wahyu serta kabar yang benar (khaabar shadiq) sebagai unsur penting. Bahkan wahyu menjadi untur konstitutif. Tujuan ilmu dan manusia tidak hanya tertuju pada dunia kini tetapi juga dunia kelak (akherat). Ilmu tidak sekedar untuk kemanfaatan manusia kini, tetapi ilmu ditujukan untuk mendekatkan diri pada sang pencipta dan dunia kelak, dunia dianggap sebagai sarana menimba modal untuk dunia kelak.

b. Tujuan moral, ada dua kata kunci yang sudut pandang kunto tentang tujuan spesifik dari moralitas, yakni Islamic Personality dan pribadi sempurna. Sosok pribadi demikian lahir dari proses internalisasi kandungan $\mathrm{Al}$ Qur'an dan hadis nabi, dengan pendekatan sintetik. Pendekatan sitentik menurut kunto, memakai nilai-nilai Al Qur'an mengandung dua hal, yaitu konsep-konsep, kisah-kisah sejarah dan amtsal.Melakukan perenungan, penghayatan terhadap niai normative Qur'an sehingga terinternalisasi dan pada akhirnya lahir perspektif moral-etik yang membentuk Islamic personality dan pribadi sempurna. Proses ini disebut dengan transformasi psikologis, sehingga wujudnya adalah sikap subjektif. 


\section{Prinsip moralitas merek dalam undang-undang nomor 20 tahun 2016 tentang Merek dan Indikasi Geografis}

Sulthon Miladiyanto, Ariyanti

Lingkup Hak kekayaan Intelektual ada istilah moral yang mirip tapi berbeda penggunaannya di Hak Cipta. Hak cipta adalah hak ekslusif pencipta yang timbul secara otomatis berdasarkan prinsip deklaratif setelah suatu ciptaan diwujudkan dalam bentuk nyata tanpa mengurangi pembatasan sesuai dengan ketentuan peraturan perundangundangan. Di Indonesia hak cipta di atur dalam Undang-Undang Nomor 28 tahun 2014 tentang Hak Cipta (selanjutnya disebut UUHC 2014).

Ekslusifitas dari hak cipta meliputi Hak Moral dan Hak Ekonomi. Mengenai Hak Moral (moral right) pengataurannya dapat di lihat dalam pasal 5, 6 dan 7 UUHC 2014. Dalam ketentuan ini disebut bahwa: 1). Hak moral merupakan hak yang melekat secara abadi pada diri Pencipta untuk: a. tetap mencantumkan atau tidak mencantumkan namanya pada salinan sehubungan dengan pemakaian Ciptaannya untuk umum; b. menggunakan nama aliasnya atau samarannya; c. mengubah Ciptaannya sesuai dengan kepatutan dalam masyarakat; d. mengubah judul dan anak judul Ciptaan; dan e. mempertahankan haknya dalam hal terjadi distorsi Ciptaan, mutilasi Ciptaan, modifikasi Ciptaan, atau hal yang bersifat merugikan kehormatan diri atau reputasinya.

2). Hak moral tidak dapat dialihkan selama Pencipta masih hidup, tetapi pelaksanaan hak tersebut dapat dialihkan dengan wasiat atau sebab lain sesuai dengan ketentuan peraturanperundangundangan setelah Pencipta meninggal dunia. 3). Dalam hal terjadi pengalihan pelaksanaan hak moral, penerima dapat melepaskan atau menolak pelaksanaan haknya dengan syarat pelepasan atau penolakan pelaksanaan hak tersebut dinyatakan secara tertulis.

Hak ekonomi dapat dilihat pengaturannya dalam pasa 8 sampai 25 UUHC 2014. Hak ekonomi merupakan hak eksklusif Pencipta atau Pemegang Hak Cipta untuk mendapatkan manfaat ekonomi atas Ciptaan. Merek adalah suatu (gambar atau nama) yang dapat digunakan untuk mengiden- tifikasi suatu produk atau perusahaan dipasaran. Pengusaha biasanya berusaha mencegah orang lain menggunakan merek mereka karena dengan menggunakan merek tersebut makaorang lain memperoleh reputasi baik dan kepercayaan dari para konsumen serta dapat membangun hubungan antara reputasi tersebut dengan merek yang telah digunakan perusahaan secara regular. Semua hal diatas dapat merugikan pemilik merek sebenarnya.

Merek adalah tanda yang dapat ditampilkan secara grafis berupa gambar, logo, nama, kata, huruf, angka,susunan warna, dalam bentuk 2 (dua) dimensi dan/atau 3 (tiga) dimensi, suara, hologram, atau kombinasidari 2 (dua) atau lebih unsur tersebut untuk membedakan barang dan/atau jasa yang diproduksi oleh orang atau badan hukum dalam kegiatan perdagangan barang dan/atau jasa.

Merek yang dilindungi terdiri atas tanda berupa gambar, logo, nama, kata, huruf, angka, susunan warna,dalam bentuk 2 (dua) dimensi dan/ atau 3 (tiga) dimensi, suara, hologram, atau kombinasi dari 2 (dua)atau lebih unsur tersebut untuk membedakan barang dan/atau jasa yang diproduksi oleh orang ataubadan hukum dalam kegiatan perdagangan barang dan/atau jasa.

Menurut Roescoe Pound (Roscoe Pound, 1945) "morality and morals are not thoroughly distinguished in general usage. It is a useful distinction to use "morality" for a body of accepted conduct and morals for systems of precepts as to conduct organized by principles as ideal systems. So "morals" would apply to "the broad field of conduct evaluated in terms of its aims, ends, or results," while "morality" would refer to a body of conduct according to an accepted stand-ard. So conventional morality would be a body of conduct approved by the custom or habit of the group of which the individual is a member." Terjemahan bebas, moralitas dan moral tidak sepenuhnya dibedakan dalam penggunaan umum. Perbedaannya saat penggunaan "moralitas" untuk perilaku orang yang dapat diterima dan "moral" untuk sistem ajaran 


\section{Jurnal Cakrawala Hukum, Volume 11 No. 3 Desember 2020}

ISSN PRINT 2356-4962 ISSN ONLINE 2598-6538

untuk dilakukan yang berisi prinsip-prinsip sebagai sistem yang ideal. Jadi, "moral" akan berlaku untuk "bidang perilaku yang luas yang dievaluasi dalam kaitan dengan tujuannya, akhir, atau hasil," sementara "moralitas" akan merujuk pada perilaku orang sesuai dengan standar yang diterima. Jadi moralitas konvensional akan menjadi badan perilaku yang disetujui oleh kebiasaan atau kebiasaan kelompok yang menjadi anggotanya.

Dapat ditafsirkan Merek yang bertentangan dengan moral sebagaimana pengertian moral menurut Roescoe Pound adalah merek yang menggambarkan perilaku manusia yang tidak sesuai dengan penilaian ideal. Missal gambar yang mengerikan, menakutkan atau menjijikan. Menurut Aristoteles sebagaimana di kutip oleh Arthur Scheller $J r$,"Morality may be equated with order and has as its object human actions that are ordered to one another and to some end. The idea of value (good or end) is the crux of any moral system since the concept of value is a primary concept in the order of our practical concepts, i.e., ultimate in its genus." (Scheller, 1952-1953). Terjemah bebas, moralitas dapat disamakan dengan keteraturan dan sebagai objeknya tindakan manusia yang diperintahkan satu sama lain dan untuk beberapa tujuan. Gagasan nilai (baik atau buruk) adalah inti dari sistem moral mana pun karena konsep nilai adalah konsep utama dalam urutan konsep praktis.

Dapat ditafsirkan Merek yang bertentangan dengan moral sebagaimana pengertian moral menurut Aristoteles adalah merek yang menggambarkan tindakan manusia yang tidak sesuai dengan keinginan umum dan tujuan umum. Missal merek gambar tindakan membunuh atau tindakan lain yang dapat memprofokasi atau menyudutkan indifidu atau suatu kelompok tertentu. "Therefore rational human nature is the norm of morality, and morality is the transformation of a known order of values. To put it quite succinctly, morality is nothing more than conformity with the rule which regulates human life: namely, the rule of reason.
Thus the essence of morality is man's approach to his goal; man's particular goal is the perfection of hisspiritual and moral nature and his ultimate goal is union with God." (Scheller, 1952-1953). Terjemahan bebas, karena itu, sifat dasar manusia yang rasional adalah norma moralitas, dan moralitas adalah transformasi dari tatanan nilai yang diketahui. Sederhananya, moralitas tidak lebih dari penyesuaian dengan aturan yang mengatur kehidupan manusia: yaitu aturan akal. Jadi esensi moralitas adalah pendekatan manusia terhadap tujuannya; tujuan khusus manusia adalah kesempurnaan sifat spiritual dan moral tujuan utamanya adalah penyatuan dengan Tuhan.

Dapat ditafsirkan Merek yang bertentangan dengan moral sebagaimana pengertian moral menurut Arthur Scheller adalah merek yang tidak sesuai dengan aturan yang mengatur kehidupan manusia untuk mencapai kesempurnaan sepiritual. Missal gambar yang menunjukan symbol agama tidak pada tempatnya sehingga menyinggung agama atau kepercayaan tertentu.

\section{Simpulan}

Sebuah merek tidak bertentangan dengan moralitas adalah suatu tanda baik gambar atau nama yang dapat digunakan untuk mengidentifikasi produk dalam dunia perdagangan barang atau jasa yang sesuai Stadar kebenaran umum maupun individual yang bersumber dari rasio manusia dan trasedental yang dievaluasi dalam kaitan dengan tujuannya, akhir, atau hasil.

\section{Daftar pustaka}

Agung Sujatmiko. 2010. Perlindungan hukum Merek Terkenal melalui Perjanjian Lisensi (Disertasi), Universitas Airlangga. Surabaya.

Amrulla, M.F., 2018. Urgensi pengaturan tentang peralihan hak atas merek sebagai objek jaminan fidusia. Jurnal Cakrawala Hukum, 9(2), pp.135141. 


\section{Prinsip moralitas merek dalam undang-undang nomor 20 tahun 2016 tentang Merek dan Indikasi Geografis}

Sulthon Miladiyanto, Ariyanti

Aristotle. 1999. Nicomachean Ethics. Translated by W. D. Book II Ross Batoche Books Kitchener.

Bertens, K. 2000. Etika. Gramedia. Jakarta.

Damian, Eddy. 2002. Hukum Hak Cipta. Alumni.Bandung.

Ibrahim, Johny. 2013. Teori dan Metodologi Penelitian Hukum Normatif. Bayumedia Publishing. Malang.

Jumhana, Muhammad. dkk. 2003. Hak Milik Intelektual: Sejarah, dan Teori Prakteknya di Indonesia. Citra Aditya Bakti. Bandung.

Mahadi. 1985. Hak Milik Immateril. BPHN-Bina Cipta. Jakarta.

Mertokusumo, Sudikno. 2009. Penemuan Sebuah Hukum Pengantar. Liberty. Yogyakarta.

Poespoprodjo, W. 1999. Filsafat Mural, Kesusilaan dalam teori dan Praktek. Pustaka Setia. Bandung.
Pound, Roscoe N.C. L. Rev. 1945. Law and Morals Jurisprudence and Ethics, Volume 23 Nomor 3.

Ridwan, 2017. Relasi Hukum dan Moral, Studi dalam Prespektif Pemikiran Hukum Kodrat, Positivisme Hukum dan Hukum Profetik. Genta Publishing. Yokyakarta.

Robinson, Luke. 2008. Moral Principles Are Not Moral Laws. Journal of Ethics \& Social Philosophy.

Saidin, OK. 2007. Aspek Hukum Hak Kekayaan Intelektual. Raja Grafindo Persada. Jakarta.

Satjipto Rahardjo, 2000. Ilmu Hukum. Citra Aditya Bakti. Bandung.

Scheller, Arthur Winter. 1952-1953. Jr, Law and Morality Artikel 12. Marquete Law Review. Volume 36 Issue 3.

Suseso, Frans Magnis. 1991. Berfilsafat dari Konteks. Gramedia. Jakarta. 